\title{
13
}

\section{COMMUNITIES AND MUSEUMS: EQUAL PARTNERS?}

\author{
Sheila Watson
}

\section{Introduction}

Relationships between museums and communities take place within the context of complex national and local political agendas. ${ }^{1}$ They require museum practitioners to understand not only the specific economic, social and political contexts of their own institutions, but also to be aware of the ways in which communities themselves use museums as a means of expressing their identities and relationships with others. Such relationships involve negotiation and compromise on both sides but sometimes excite strong emotions that make dispassionate and impartial negotiations difficult. Museum professionals may become defensive of their expertise and reluctant to share control over knowledge, though eager to impart their own. Some communities, in turn, may be resistant to change in "their museum," vesting energy in maintaining the status quo. Others demand new ways of practice and knowledge sharing and control that challenge a Western ideal of freedom of expression (Lagerkvist 2006), while some may have no understanding of how to work within the existing framework of knowledge and power that museums represent, and thus find themselves marginalized. Resistance to change by those familiar with the conventional performances of the museum space may be characterized as negative and reactionary while newer voices are welcomed. Those who were previously marginalized may, however, be as exclusive as some existing supporters. For many museum practitioners what results is a balancing act-policies that enable the museum and gallery to change and develop but ones which avoid confrontation with existing stakeholders.

Over the last decade, or so, a great deal of attention has been paid to the ways in which museums shape memory and identity. However, less emphasis has been placed on understanding the sophisticated ways in which groups of people, claiming to represent community interests, manage and control certain types of community resources such as gallery spaces, in order to maintain their sense of self-esteem and separateness from others, despite the best endeavors of museum practitioners to prevent this. There are some well-documented examples in which certain groups have successfully mobilized to oppose certain types of exhibition, 
such as the Enola Gay (e.g. Dubin 1999), and there are many examples of the questioning of Western knowledge principles by minority indigenous groups (e.g. Hooper-Greenhill 2000, Macdonald and Alsford 1995).

However, there are, on the whole, fewer attempts to review and critique the ways in which communities in the West control the museum process to maintain their power over the institution in practice. It is in this context that this chapter seeks to understand some aspects of the work members of the Great Yarmouth museums team undertook over a seven-year period when, working in partnership with a range of organizations that included the National Trust, English Heritage and the local borough and county authorities, they sought to find new ways of working with different communities and new roles for the sites they managed, and to establish relationships with individuals who would not normally ${ }^{2}$ visit museums. During this period they conducted many different types of consultation exercises and used focus group work to help shape and develop all of the key developments in the town. This case study will explore the way in which certain groups, claiming to represent wider community interests, resisted change and, in so doing, maintained their privileged positions. It also examines how and why particular types of material culture and the ways they are made accessible are deemed to be particularly important to some community groups in the United Kingdom.

This chapter also seeks to understand the relationship between theory and practice. A great deal has been written in academic discourse about museum relationships with communities that seeks to understand the ways in which institutional structures and practices inhibit, marginalize or exclude certain types of people (e.g. Bourdieu and Darbel 1997; Merriman 2000; Hooper-Greenhill 2000; Sandell 2002; Marstine 2006; Watson 2007a). What is less clear is the extent to which such theoretical approaches, even when rooted in specific case studies, actually help museums understand and manage their relationships with communities. Danielle Rice, writing about the art museum, argues that the relationship between most theorists and museum practice is non-existent to the extent that academics are concerned with an "illusory museum" (Rice 2003: 77). This, perhaps, rather overstates something that is, nevertheless, a dilemma for those working in and studying museums - the complex relationship between theory and practice- how to liberate theory from the abstract negotiation of ideas and apply it to the issues that relate to everyday museum practice. It also underestimates the impact upon museum practitioners of training in museological theory that encourages them to experiment and reflect on their theoretical understanding of museum work. What is often lacking is time for those working in museums to write about their experiences and reflect on them. The particular projects described here are now long over, so there is opportunity to think through some theoretical issues that might help explain how and why events unfolded as they did and the lessons learnt.

\section{Background}

Great Yarmouth's sandy beaches and relatively dry climate have led to its development as a tourist resort. At the time of the 2001 census, it had just over 90,000 inhabitants (Census 2009). In 2008 the Pleasure Beach attracted 1.4 million visits (Warburton 2009), from mainly working class visitors. Many local people work long hours in the summer but are unemployed in the winter. Pay is relatively low. In 2000 official indices of deprivation placed Great Yarmouth fifth worst in ward level intensity out of 354 local authority districts (GYBC 2004). Great 
TABLE 1 NRS Social Grade Definitions (UK) Social Grade (UK)

\begin{tabular}{|c|c|c|}
\hline A & upper middle class & higher managerial, administrative or professional \\
\hline B & middle class & intermediate managerial, administrative or professional \\
\hline C1 & lower middle class & $\begin{array}{l}\text { supervisory or clerical, junior managerial, administrative or } \\
\text { professional }\end{array}$ \\
\hline C2 & skilled working class & skilled manual workers \\
\hline D & working class & semi and unskilled manual workers \\
\hline $\mathbf{E}$ & those at lowest level of subsistence & $\begin{array}{l}\text { state pensioners or widows (no other earner), casual or } \\
\text { lowest grade workers }\end{array}$ \\
\hline
\end{tabular}

Businessballs.com 2010.

Yarmouth was and is a predominantly poor working class town with pockets of middle class affluence in its suburbs. For the purposes of this chapter the words working class and middle class will be defined according to the classification system given in Table 1 .

While it is recognized that this is a simplistic and problematic method of categorizing people in the UK, one that fails to distinguish a range of complex social, cultural and geographical factors that influence the notion of class, this was the system upon which the original recruitment for the consultation in Great Yarmouth was based and is therefore useful for the purpose of analyzing the relationship of different groups of people to heritage in the town. Moreover, this is the way in which the UK government sometimes classifies people when assessing the success of social inclusion targets (e.g. Martin 2003).

Over the last couple of decades politicians in the UK have tended to avoid the word "class" when describing communities that have low incomes and fewer educational qualifications than professional groups (Bennett et al. 2010: 2). The words "disadvantaged" and "excluded" are more common than "working class," and emphasis in social policy has been on combating poverty and subsequent social exclusion. However, recently there has been a shift in attitude towards recognition that class matters and that, in particular, many white working class individuals feel ignored by government policies, with a consequent turn by some disaffected individuals to right wing racist politics (Wheeler 2010). John Denham, Secretary of State for Communities and Local Government, spoke about the need to ensure that white working class families and individuals did not feel disadvantaged and pointed out that class was a serious issue for British politics. He argued that "class still matters in Britain and the politics of identity ignores it at its peril" (cited in Wheeler 2010). At the same time there has been growing interest in class as a means of understanding attitudes to culture that revisits Bourdieu's classic deconstruction of class and taste (Bourdieu 1984; Bennett et al. 2010). A revival of interest in class and heritage is not just limited to the UK. For example, in the United States, Tamasin Wedgwood has undertaken research into the work of the Textile Heritage Centre Cooleemee, North Carolina and the ways in which working class communities practice history and heritage (Wedgwood 2009a; Wedgwood 2009b).

Great Yarmouth is not somewhere most professional or middle class people would chose to visit for a seaside holiday. In 1996 focus group work with day visitors to Yarmouth, carried out in Norwich, the county town of Norfolk, on behalf of the Great Yarmouth Heritage Partnership revealed unremittingly negative attitudes towards the town not only from the relatively wealthy and educated $\mathrm{B}$ and $\mathrm{C} 1$ groups, but also from those in social housing living 
on a low wage or on income support in the $\mathrm{C} 2, \mathrm{D}$ and $\mathrm{E}$ categories. ${ }^{3}$ The report of the consultation with all these groups revealed a surprising unanimity. Susie Fisher, the author, stated "Yarmouth is where they are slumming it ... Norwich people exploit Yarmouth. If it is fulfilling a useful function they'll take it [i.e. they will use the beaches and have fun] but they will be the last to respect and endorse it." (Fisher 1996: 9) Yarmouth, she went on to say is a place that is "tacky, tatty, ... no pretensions." Norwich itself was "their spiritual home, old established, cultured, sure touch with Arts and Museums." For them Yarmouth was all they were not and they showed active hostility to any idea that Yarmouth should try and improve its museums and market its heritage side. One focus group participant in Norwich, on being told that Great Yarmouth wished to make more of its heritage attractions stated "Great Yarmouth is trying to make itself better than what it is." (ibid.; see also Watson 2007b: 162-63)

Focus group work with Yarmouth residents indicated that they too despised the town and their impressions of the place in which they lived were summed up in the following way:

How can I get out? I'm trapped here

Unemployment

Fractured families, child responsibilities

Broken down buildings, pride slipping away

Summer visitors don't care for the town-a danger to my children: drugs, drunks and transients.

(Fisher 1996: 8)

Over the following seven years the Heritage Partnership, working collaboratively with community members, consulting representatives from all sections of society, (using focus groups held on a regular basis), redisplayed four museums, one ancient monument, ran a community excavation and finally created a completely new museum (opened in 2004) where the town's people chose everything from its location to its name, Time and Tide: Museum of Great Yarmouth Life.

Great Yarmouth, like most places in England, has a long history, going back at least a millennium. It was reputed to have been the fifth most important town in the country during the Middle Ages. However, despite the complexities and myriad stories that such a history embodies, consultation over several years indicated a consensus amongst all groups of people and sections of society about certain types of stories important to the town and the methods of telling them (Watson 2007b; Watson et al. 2012). Yet such democratization was not always easy, despite genuine attempts to involve local community groups and focus groups at every stage of the developments. Disagreements arose over the way in which certain types of objects were to be used to tell the stories and these throw some light on the way in which certain groups in society attempt to manage, control and manipulate heritage to support their own sense of identity and their status. The most difficult and challenging disputes arose over the role of fine art in the Borough and the relationship of the Art Galleries to the new museum.

Formal academic classifications such as art, archaeology and geology were rarely discussed during the consultation process as most people were concerned with themes and ideas of what was important in the town's history. Most of the consultation was to do with the refurbishment of historic sites such as English Heritage's Old Merchant's House, Greyfriars' 
Cloisters and Row 111 House, the Borough's Tolhouse Museum, the National Trust's Elizabethan House Museum, or the new Museum, the Tower Curing Works, later called Time and Tide: Museum of Great Yarmouth Life. The Norfolk Museums and Archaeology Service (NMAS), which managed the Tolhouse and the Elizabethan House, was also responsible for the Great Yarmouth Art Galleries, a suite of three large exhibition spaces where temporary exhibitions were held, situated above the Central Library in Great Yarmouth. Đuring this period, I managed the Yarmouth Museums run by NMAS and chaired the Heritage Partnership. Some focus group sessions took place in the Art Galleries between exhibitions, when objects from the stores in the basement of the library from social history collections, ethnography, archaeology and art, were placed at intervals on tables or against walls. The groups were encouraged to select the ones they thought were the most important and to say why. The art collections were universally admired. In particular, people who had never before attended an exhibition in the gallery or visited a museum expressed great enthusiasm for the images. They liked the stories implicit in the paintings, many of which showed fishermen and women on the beach or the town in the past. Several of them expressed surprise that such paintings existed and were keen to find out more about the stories in the paintings. While they did not comment on the aesthetic, they did talk about the quality of the paintings as being "fine" and "clever." In 1997 focus groups were specifically asked if they wished to see art in a gallery or in a general museum setting amongst other collections. With the exception of representatives from two local art societies all members of all groups expressed a preference for the general museum setting with specific requests for the art to be placed in cultural and historical contexts.

The Galleries themselves were available for hire by community groups when they were not being used for the museums' temporary exhibition program, and some groups booked them annually. The fees for hiring the Galleries for a week or two were very small, and the spaces were prestigious. Entry into exhibitions was free for both museum-led and community organized exhibitions. Several local art and photographic societies held annual shows in which they sold their work to the public. One popular exhibition "Pictures for the People" was held annually, a few weeks before Christmas. Anyone could exhibit any picture as long as it was for sale. No aesthetic judgment was applied to the work. The tradition of community use was therefore well established and we considered our relationship with the various societies who exhibited there to be good, if not excellent. Thus the Galleries were a mixture of the popular, democratic and the elite and aesthetic. Nevertheless, despite the fact that the Galleries were located in one of the most deprived areas of the town, few people from the surrounding area visited them. Exhibitors and visitors were mainly middle class and from the more affluent suburbs, or the surrounding countryside, and were very supportive of our exhibitions, often driving some considerable distance to see them, as well as hosting their own.

\section{The Galleries and the Shipwreck exhibition}

In 1999 we planned an exhibition to commemorate the sinking of the Lutine-a ship that sailed from Great Yarmouth in 1799 and then sank. It became memorable because Lloyd's of London, the insurance underwriters, paid compensation to the owners and secured the bell from the ship "the Lutine bell," which became synonymous with the institution. It was rung once to announce the loss or destruction of anything Lloyds insured, twice to announce a recovery such as the return of a ship thought lost at sea. The ringing of the bell is now largely confined to ceremonial occasions but it is still rung to indicate exceptional disasters such as 
the destruction of the World Trade Center in New York City on September 11, 2001 (Lloyd's 2010). The Lutine bell is known within insurance circles all round the world-by many people who do not know what the bell is or why it is rung.

The Shipwreck exhibition enabled the museums to display some of their fine shipwreck paintings (Figure 13.1). Lloyd's generously sponsored the exhibition and loaned objects for it. Like many museums and galleries we wished to try and widen our audiences for the exhibition. We knew from visitor surveys that people from the local community rarely came to our art exhibitions.

About this time the principal of Great Yarmouth College approached the museums service asking to rent the Galleries for a short period of time. He wished to use them to house computers with learning programs for adult basic skills education (mainly literacy programs)

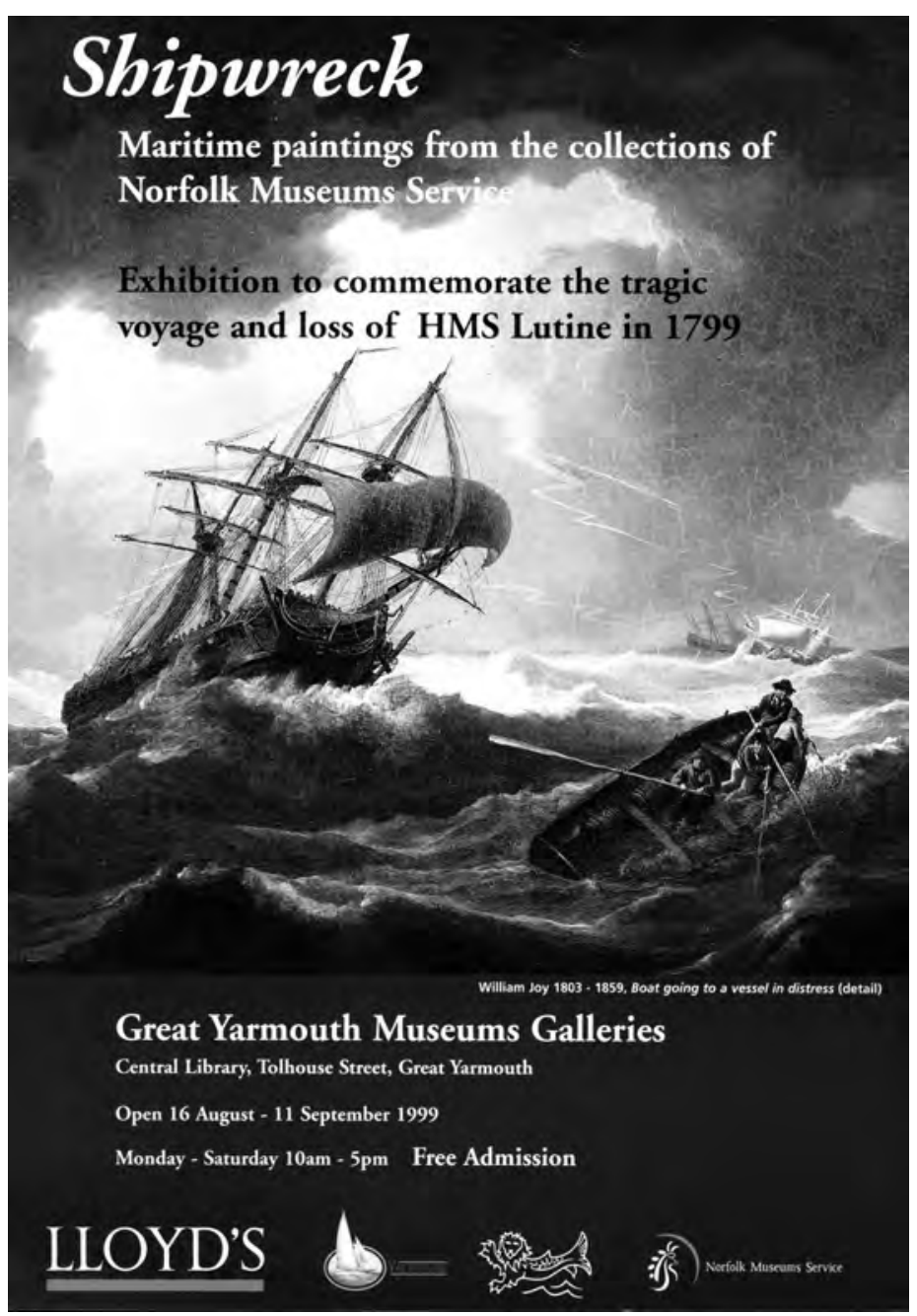

FIGURE 13.1 Poster advertising the Shipwreck Exhibition at the Great Yarmouth Galleries.

Reproduced by kind permission of Norfolk Museums and Archaeology Service. (C) Norfolk Museums and Archaeology Service. 
in an "EasyLearn Centre." The College was located some distance away and he wanted to find an outreach station in this particular area, for adult basic skills education services. Exhibitions would continue with the computers in the center of two of the Galleries. This would bring new audiences into the Galleries. At the same time the College would pay a fee for the use of the space which, in turn, would fund more exhibitions. We agreed that if we went ahead with this it would be for six months only. However, before we decided to take this unusual step of changing the art gallery into a hybrid space to encourage literacy as well as the appreciation of art, we consulted our stakeholders, in particular the regular users of the Galleries including local art societies. One society representative expressed concern at the idea of the computers and the College agreed to remove the computers during the fortnight of this society's exhibition period. Consultation also took place with the museums committee, composed of elected members and officers and they wholeheartedly supported the experiment.

Each gallery had eight computers - in rows of four facing each other. There was still plenty of space within the Galleries for those viewing the paintings on the wall to do so in comfort. The computers not only had literacy programs, but also information about the paintings and screen savers with pictures from the exhibition. This was designed to encourage people to look at the exhibition if they had just come to access the adult basic skills program. At the same time visitors to the Galleries who had come to see the exhibition were encouraged to access digital information about the exhibition from the computers - a catalogue that allowed visitors to explore the ideas of the exhibition further. There was to be no stigma attached to being seen on a computer. No one in theory would know if someone was using a computer because they were having basic skills training or were reading something about the exhibition. The adult basic skills programs offered in the Galleries were "drop in."

Adults with learning difficulties sometimes find it hard to commit to coming at set times and may be inhibited from working with a tutor in a formal classroom environment. Here, however, access to the materials was easy. The College advertised the computers' presence and provided a tutor in the Galleries whenever they were open. Individuals came and went as they were able or felt inclined and would either access the computers on their own or through the help of the tutor. We checked with Lloyd's who were delighted with the idea and even provided some extra funding for the digital catalogue. On the opening night I took the chairman of Lloyd's around the Galleries and he was enthusiastic. He thought it provided an innovative way to encourage people who did not usually go to exhibitions to see them and made a positive reference to this new use of the space in his opening speech.

Within the first hour of the public opening of the exhibition, as manager of the museums and Galleries I had complaints from some regular museum and gallery visitors. These complaints were varied, but they focused on the perceived inappropriateness of mixing computers and art and the anxiety felt by the traditional visitors that the users of the computers were not "their sort of people." One individual from one of the local art societies asked to meet me in the Galleries so he could tell me what he and his friends felt about our experiment. He stood in front of one of the paintings and pointed to the computers. He complained that the people using the computers for adult basic skills education could not understand art and should not be there. The people to whom he referred were working quietly at the computers and were indistinguishable from any other member of the general public.

Of course, not all the traditional visitors objected. We conducted evaluations in various ways - with a visitors' book, and evaluation sheets in the Galleries, and through front-of-house staff that were told to write down comments they received-both positive and negative. ${ }^{4} \mathrm{We}$ 
also asked the front-of-house staff to call me to come to the Galleries (my office was just across the landing) if people wished to complain. We also, with permission from the College, asked some of the adult basic skills users about what they thought of the exhibition. When we combined these evaluation strategies and analyzed the results we found that 98 percent of the visitors who responded to the evaluation: (1) did not notice the computers; or (2) feel strongly about them; or (3) therefore did not comment on them negatively; or (4) used the computers to access information about the exhibition and therefore liked them. A few wrote positively about them in the visitors' book. Two percent of those who took part in one or other form of evaluation disliked them.

This small minority, many of whom came from local art societies, wrote to the local newspapers, campaigned with local councilors, haranguing them and me at every opportunity. My competence as a museum professional was called into question in public. The number of complaints, the persistence of the opposition and the determined way in which they attempted to rally support went beyond anything I had experienced or anticipated. However, all the elected members and officers as well as the head of NMAS (to whom I reported), and her line manager, the head of Cultural Services in the county, remained steadfastly supportive throughout. While not anticipating such a reaction to the experiment I had been careful to involve all the key political players, officers and committees in the final decision to work jointly with the College. When these individuals continued to support the experimental joint use of the Galleries the local Member of Parliament was approached and he telephoned me from the House of Commons to find out what the problem was. The MP took time out of his busy schedule to come and see the exhibition, talk to me, and then expressed nothing but enthusiasm for the innovative use of this public space and the idea of attracting new visitors to the Galleries.

Evaluation of the adult basic skills education users showed that none of them before had visited an art gallery, all of those questioned had looked at the paintings and said they enjoyed them, and approximately 50 percent of those who responded said they would come back again to the Galleries after the experiment with the computers had ended and look at other exhibitions we held there. The tutor who worked in the Galleries and the front-of-house staff on duty reported that the adult basic skills users of the computers would get up from the computers when they needed a break and would look at the paintings and talk about them to the staff there. She was asked to write a brief report on her views of the shared space during the Shipwreck (Lutine) exhibition. She commented:

The Lutine exhibition provided a great opportunity for our EasyLearn client base. The majority of the students who attend the EasyLearn Centre are unlikely to have enough confidence to enter a gallery to view an exhibition. In fact the amount of courage it has taken in some cases to even enroll in a computer course is astonishing.

Art is often perceived as being for an elite audience, so it was very gratifying to see the students gradually start to look around and enjoy the exhibition. It would be nice to see more dual use of this type of facility to reach a wider audience. ${ }^{5}$

In that sense the experiment had been a success. We had widened our audiences but at the cost of alienating a few of our hitherto most loyal supporters.

The relationship with these now ex-loyal supporters took a long time to heal. We were perceived as people who did not appreciate art because we dared to suggest that art was more 
than an exclusive elite experience that only a few could understand. We opened up the Galleries to others and offered to share the art gallery space with a different organization with different purposes and values. As there was so much vocal opposition to the scheme, no plans were made to take the experiment any further and the computers were removed from the Galleries after six months. The opponents to museum policy won that battle. They valued the Galleries highly and made a great deal of use of the word "community" in their opposition, claiming that the "community" did not like this kind of shared space. They only spoke, however, for their kind of community-one that understood the art gallery as an institution that separated those who understood a certain type of knowledge from those who did not and which functioned as a place apart from daily life. Nor was this attitude exceptional. Silverman's (2010) account of the ways in which some museums have evolved to support different types of social work highlights some of the main criticisms of such practices. She cites James Cuno's (1997) arguments that these developments threaten scholarship. Appleton's (2007) dislike of the needs of people as a focus of curatorial attention is based on similar fears. Thus these individuals were merely voicing relatively common concerns (albeit in a more assertive manner than many) about the perceived threat of new uses of galleries to traditional values.

Public criticism over time shifted from complaints about the students' presence in the Galleries to a dislike of sharing art spaces with computers. The change appears to have been a response to a realization that negative comments about those with learning difficulties from less affluent and more disadvantaged backgrounds were unacceptable and detrimental to their cause. However, the fundamental objection remained, manifest in ongoing discussions held in my office-these people were unappreciative of art and this somehow made them unsuitable as quiet students in a gallery space. At face value the issue appears to be one of class, where a small group of middle class individuals took a stand against the use of the Galleries by those with different backgrounds and educational levels from themselves. However, drawing on theory and experience in practice, I will suggest that the situation is more complex.

\section{Art and class}

Let us first look at the theory behind this sort of behavior. In her study Culture and Class in English Public Museums 1850-1914 Hill (2005: 4) concludes that "museums were used by bourgeois elites to create distinction and legitimacy for themselves, and even to try and improve or control the working class ..." She argues that this was not very successful and that working class visits to museums declined but that members of the lower middle class were effectively encouraged to see museum visiting as part of their cultural milieu. Taking this idea further we can see that over time the practice of visiting the gallery acquired a certain type of behavior, which was associated with contemplation and the admiration of the aesthetic. This in turn became a measure by which those who patronized the Galleries could judge themselves as knowledgeable consumers of culture. Indeed, it could be argued that "... the rituals of leisure and the performance of the visit are important components in the history of the visibility of these cultural institutions ..." (Trodd 2003: 17) Thus the mixed use of gallery space with a work environment might be understood to be challenging the notion of the performative space where pleasurable contemplation was expected.

However, perhaps we can understand it a little better if we consider it within the context of class relationships and the way in which class is related to the concepts of both an aesthetic 
and romantic gaze. Urry notes that romanticism was involved in the development of mass tourism and was adopted by the middle classes as a way of enjoying leisure time. In turn it encouraged certain middle class leisure seekers to holiday in places such as the Lake District where romantic views were plentiful. This notion of romantic nature was, as Urry points out, a "fundamentally invented and variable pleasure" (Urry 1998: 46). Nevertheless, it became associated with middle class values while, at the same time, the enjoyment of less visual and contemplative pursuits became associated with everything that was vulgar and working class. Those who objected most to the presence in the Galleries of those whom they claimed did not understand art tended to pursue an ideal in their work which sought to reproduce the romantic gaze, mainly landscape paintings with a few portraits and flower paintings.

Art galleries have long been associated with certain cultural practices and functions. For those who are familiar with them they represent a place of "aesthetic refuge, conservation and contemplation" (Trodd 2003: 17). At the same time there are many theorists who see them as places of governmental control, authority, civic rituals and regulation of manners (e.g. Hooper-Greenhill 1992, Duncan 1995, Bennett 1995). Some research has been carried out on the way in which certain communities regard art galleries and the art within them (e.g. HooperGreenhill and Moussouri 2001; Hooper-Greenhill et al. 2001; Trevelyan 1991; Bennett et al. 2010), including the hugely influential work on class and visitor behavior in French art galleries by Bourdieu and Darbel (1997 originally 1969). There is a general understanding that the art gallery presupposes certain values that have more importance than others. These values are associated with the aesthetic experience and " ... as long as we have the right kind of understanding, the value of a work of art lies its rewarding with pleasure the contemplation of its aesthetic virtues, independently of any further end or goal" (Kieran 2005: 296) [Emphasis added].

However, research has established that such values are difficult for some groups to understand, particularly those from a working class background with little experience of the aesthetic distancing of middle class taste (Bourdieu and Darbel 1997). Thus art in galleries becomes the signifier of a particular type of cultural capital to which middle class groups are particularly attached both because of their enthusiasm for certain cultural activities such as viewing art in museums, and their interest in art as a commodity that can be bought and sold. Indeed we might go further and consider that this is as much about cultural literacy as aesthetic literacy (Simpson 1991).

Museum visiting in the United States is predominantly a middle class activity and in the UK it is significantly higher amongst those of A, B and C2 classes (Prior 2003: 58). Attempts to attract new audiences to art Galleries in the UK have included, since December 2001, the adoption of free entry into national museums. Between 1999 and 2002, according to an Ipsos MORI report, ${ }^{6}$ the proportion of visitors to a museum or gallery in the United Kingdom, over a three-year period, from the $\mathrm{AB}$ category rose from 56 to 62 percent, in the $\mathrm{C} 1$ category from 39 to 53 percent in C2 from 29 to 39 percent and in DE groupings from 23 to 25 percent (Martin 2003: 5). In other words free entry attracted more visits from the groups that already visited the museum most frequently. The MORI report pointed out:

Unfortunately for those claiming that free entry has acted significantly to improve social inclusion, the proportions of certain sub-groups within the population who claim to have made more visits as a result of free admission make depressing reading. While $15 \%$ of the British public say they have made more visits, this rises to $20 \%$ among ABC1s, 21\% among people living in the South, and 29\% among people with a degree. 
Thus free entry alone removes only one of a suite of barriers to entry for the D/E groups, although it does have some influence on those from the $\mathrm{C} 2$ group. This was evident in the Great Yarmouth Galleries, whose visitors were on the whole members of the middle classes and who were frequent museum goers, despite the fact there was no charge. In the UK many people with limited education and lower incomes will not come to galleries even if they are free, and are thus less likely to be conversant with gallery visiting behavior, which is highly formalized. It is a vicious circle of exclusion. The complaints from visitors (who did not like the computers in the Galleries) that the people using them did not understand the milieu is possibly true, though it does not mean they could not appreciate and enjoy the art on display.

So how do museums deal with the issues of inclusion? There have been attempts to reach out to different communities by challenging traditional methods of display. Much museological literature is influenced by the ideas of Michel Foucault where assumptions are made about the ways in which institutions reinforce traditional power structures and visitors are expected to understand the formal and traditional knowledge that underpins the exhibition, even when it is challenged by the museum itself. Rice, writing about the much acclaimed and ground breaking exhibition by Fred Wilson at the Maryland Historical Society, in which objects relating to slavery and the oppression of African American people were juxtaposed with fine art collections, recounts her experience of walking through the exhibition with an African American friend who was baffled by the experience and could not understand how a museum could be so critical of itself (Rice 2003: 82). Rice makes the important point that even when museums take a critical view of their traditional practices, the visitor will need to be aware of the tradition to understand the criticism. Though the Wilson exhibition attempted a certain type of inclusion it, nevertheless, still remained difficult to understand for those unfamiliar with the conventions of museum display and the significance of the innovative practices Wilson deployed. While we need to undertake more visitor studies to understand why individuals do not visit museums and Galleries, most academics perceive art galleries as institutions that present a form of hierarchical knowledge that can be deeply off-putting to those who do not possess the visual literacy needed to apprehend art. Without a background of art gallery visiting such individuals are unlikely to be comfortable with exhibitions that transgress this understanding of art.

Traditionally, curators have seen themselves as authorities on taste and aesthetics (Benton and Watson 2010:130). On the whole the public trusts curators. As McClellan argues:

At the same time and in direct proportion, a viewer's confidence in passing aesthetic judgments decreases beyond a museum's walls. The public's confidence in such matters is never great, but museums exist to provide essential guidance and reassurance and, by and large, the public is content to follow the lead of professional curators and educators.

(McClellan 2003: xiii)

This may well be true but experience suggests that if the museum changes the ways in which it mediates the aesthetic experience, either by introducing certain types of interpretation that presume little or no understanding of the conventions or, as in this case, by mixing the function of the museum so that aesthetic experience shares a space with another activity, it may succeed in attracting new visitors but also angers those who see themselves as guardians of the aesthetic tradition. Mark O'Neill in his description of the criticisms of the reaction to 
“The Birth of Impressionism” exhibition in Glasgow in 1997 cited the following newspaper review:

I will be blunt ... this is simply the worst exhibition I have ever seen ... It is crass, unintelligible and a positive danger to the general public. What we have here is not an art exhibition at all, but a history lesson ... in which the pictures become mere tools ... as the father of a four year old I would be happy to take my son here, but were he a year older, I would think twice. Art demands space, light and silence.

(Gale 1997 cited in O'Neill 2002: 32)

The most interesting thing about O'Neill's honest and painful account of the attacks the museum received for exhibiting impressionist paintings alongside some contextual and historical information is that the critics focused on the visitors who were not "good enough" to understand art in its traditional forms. In a similar way some opponents of the dual use of the Galleries with the EasyLearn Centre focused on a presumed inability (of those who were voluntarily trying to improve their literacy skills) to appreciate art in a formal gallery setting. It might, therefore, be seen that this opposition is knowledge based, a fierce defense by one group of the use of a space and cultural assets against others who might not possess the same knowledge that they do and may therefore behave differently in a space reserved for quiet contemplation. However, O'Neill makes an interesting point that "many who feel comfortable in art museums know little or nothing about art, but have the crucial understanding of how museums work, and this enables them to feel that they belong" (O'Neill 2002: 35), and this opens up a possibility that the art itself is not seen to be undermined in some way by its juxtaposition to other forms of material culture and interpretation (Glasgow) or computers (Great Yarmouth), but rather what is threatened is the sense of belonging and ownership that certain people have when they enter a museum or gallery. The museum offers a range of activities that allow not only the aesthetic, but also "entertainment, connoisseurship and consumption, private delectation and public provision" (Prior 2003: 63) [Emphasis in original work]. Thus museums, while leaning towards one tendency or another rarely embrace one activity only. However, these activities have to be within a conventional framework of what is acceptable in an art gallery space. We can see that for some people the presence of individuals with limited literacy skills and from less privileged backgrounds was not compatible with their concept of an art gallery and the visitors they expected to meet there.

As museums in the twenty-first century are urged to move towards more participatory practices, some practitioners have found entrenched resistance to change. While there is no lack of inspiring examples of museums working in new collaborative ways and promoting the welfare of people in society (Simon 2010; Silverman 2010), for all the successes in this area, there are also projects like this one which inadvertently worsen relationships between museums and some visitors. Often local circumstances play a significant role in such relationships and it is to these I turn now.

\section{The importance of local contexts}

Since the mid-1960s there has been a move towards attempting to understand the local. "Michel Foucault's The Order of Things (1966) and The Archaeology of Knowledge (1969) made 
knowledge, understanding, meaning, value, and the material fabric of society, a product of local circumstance in time and space ..." (Knell 2007: 14) Perhaps the local context will help us to understand community resistance to change in a more nuanced way.

Great Yarmouth societies associated with art have long, proud traditions. In most, and like similar societies elsewhere, membership is exclusive and only those whose works are considered to have reached the appropriate standard are admitted. This standard is rooted in a certain formal artistic tradition. Writing about the importance that some place on the concept of "quality" in art works Stephen Weil writes “... for those who hold this view, the primary role of the art museum is clear ... it is to distinguish works of art of greater quality from those of lesser and to make those greater-quality works of art accessible to the public" (Weil 2007: 101). For some this emphasis on quality is about control by certain sections of society over others (ibid.: 102-3, Bourdieu 1984). They see themselves as arbiters of taste and aesthetic beauty. The idea of the aesthetic implicit within their argument (that art did not need interpretation for "aesthetic pleasure") is based on the concept of something that defied meaning and followed a Kantian idea of art as a "dynamic mechanism operating according to a kind of complex internal logic that both invites and eludes interpretation" (Gero 2006: 5 citing Kant's 1790 work, Kritik der Urtteilskraft).

For those who adhere to these concepts of the role of art, the art gallery is a formal space for the display of art that should be understood by those who view it, without interpretation or explanation. It is an easy step from this position to one where they come to regard those who require interpretation or explanation as somehow "not belonging." This helps to explain, though not condone, the reaction of some visitors to the Shipwreck exhibition to the users of the literacy programs in the Great Yarmouth Galleries.

Perhaps we can also understand their defensive behavior and their desire to keep computers and mixed usage out of the Galleries as a means of opposing change. Great Yarmouth had suffered a major economic decline and was no longer the proud and prosperous place it had been when these societies had first been founded. For some visitors this new use of the Galleries was a decline in standards and a threat to a proud tradition. Galleries have status and prestige attached to them. If their role is somehow diluted some of that status and prestige is lost. Pride is something that few museum or gallery workers consider when developing relationships with communities. However, Tamasin Wedgwood's research into deprived communities in America finds that what was perhaps most significant was that both black and white residents of the North Carolina community of Cooleemee engaged with history and museums as a way of seeing history as "a narrative of triumph over adversity that teaches hard-work, and service to community" (Wedgwood 2009b: 185), a means of passing on these values to the next generation. They engaged with heritage because it made them feel proud. The work of the artists who exhibited in the Galleries no doubt encouraged similar feelings of pride. In both cases exhibitions were about the self-esteem of a community. The dedicated art space was a tangible symbol of the high regard in which art in the town was held and, in turn, provided the town with an important cultural symbol.

Members of the public who exhibited in the Galleries also sold their art works. Perhaps opposition to the dual use of the Galleries was partly based on anxiety, not articulated but nevertheless deeply felt, that this reshaping of the use of the space would result in a reduction of the numbers of the type of people who were prepared to spend several hundred pounds, if not more, on a work of art. It might also have been seen as a devaluing of the work itself by its association with those who some might think had no aesthetic sensibility. 
Urry's work on the collective gaze and the importance of the presence of others like ourselves "in constituting the attraction of certain places" (Urry 1998: 140) helps us understand the reaction of certain members of some of the art groups in the town to the notion of shared space. Perhaps the Galleries, while belonging to the community as a whole, were understood emotionally to belong to some groups within that community more than others and be part of the ways in which such groups articulated their identities.

\section{Is compromise possible?}

As a direct result of the disputes between museum staff and some stakeholders an independent consultant was appointed to investigate and report on the use of the Galleries. He recommended that these become community spaces where people could exhibit, run by a committee of stakeholders. While welcoming this move to an apparently more democratic and inclusive use of the space representatives on the committee were, on the whole, those who opposed changes. The museums service withdrew from maintaining these Galleries and handed them over to the Library service to manage. Compromise proved impossible and we decided to pursue our attempts to widen access to art in another venue.

Time and Tide: Museum of Great Yarmouth Life which opened in 2004 displays the museum service's fine art within the narrative themes chosen by community groups alongside other material culture. There is a small temporary gallery where different types of exhibitions are held-some art focused. These are often developed with the help of individuals from the community. Over the Christmas period 2009-10 a community exhibition was held called Our Choice: We Know What We Like. Publicity stated that "This exhibition features art works from our collections here in Great Yarmouth. These have all been chosen by local people and community groups" (NMAS 2009). A study of the labels in this exhibition reveals that few people select paintings on aesthetic merit alone, or indeed mention art historical themes or critiques. However, it is clear that the art moved them in some way.

Many chose images that reminded them in some way of the past and used them to reminisce. For example, a man chose a watercolor by Anthony Amies, a well-known Yarmouth artist, of "Great Yarmouth Market Place and Chip Stall." This enabled him to write in his label,

this was the heart of the town where people would meet to pass on any news and gossip to anyone who was ready to listen. Even though I was eight years old when the picture was painted it reminds me of the time with my grandparents and parents on the stall ...

Here different ways of seeing illustrate how individuals respond to the personal and the particular and how certain groups of people form "interpretive communities" where they prioritize their communal experiences (Hooper-Greenhill 2007).

In another example, a lady who now lives in Yarmouth describes a watercolor of two birds by Frank Southgate, famed for his natural history illustrations:

This picture brought back many memories of traveling from Norwich to Great Yarmouth, 52 years ago by train ... Family trips over the years would give us peace and tranquility, and also amusement watching the ducks and geese and their antics... the artist has produced a real life version that questions the season or time of day that is appealing. 
Here the author shares a personal meaning that is rooted in her sense of family and her past. From this she develops her own aesthetic appreciation of the artwork deeply rooted in her feelings of her own history. In their study of visitors' reactions to art, Hooper-Greenhill and her research colleagues noted that the interpretive strategies available to visitors were developed slowly and refined with practice. "The strategies each visitor developed depended on who they were as learning is closely related to identity" (Hooper-Greenhill et al. 2001: 29).

Other contributors do not disclose their personal attachments and readings but focus on their own understanding of beauty and art. A woman from a sheltered housing complex chose a picture of the beach painted in 1840 by the well-known East Anglian artist John Berney Crome. She wrote on her label: "I have chosen this picture because I thought it was beautiful. The effect of the moonlight scene is so different to anything by daylight. It has a mystery and magic about it, a quiet beauty, interesting and fascinating ..."

Some label writers refer to the picture they chose in traditional art historical ways. For example a group of amateur artists from Art Regenerating the Community (ARC) wrote of a Joseph Nash (1835-1922) picture of "Great Yarmouth Harbour Entrance”:

What particularly struck us about many of the older art works and specially those which the group selected is the tenderness with which the artist handled both subject and materials: nothing sentimental, but a confident breadth of skill in observation and image construction that allowed the subject to shine through to our own day.

This is the exception rather than the rule. Most who chose a painting did so because they just liked it for personal reasons that link to their memories and engaged them. Here prestigious art has become accessible to those who rarely enter an art gallery.

\section{Conclusion}

Theories relating to museum practice influenced the projects described here but, as the first example has shown, public resistance to innovation and change, in defense of customary gallery uses, was fierce. The difficulties facing the museums service in 1999, which culminated in public confrontation between museum staff and some community members who represented the views of some traditional visitors to art galleries, expose some of the problems museums encounter when they attempt to widen access to museums. This incident suggests that certain groups and individuals can maintain their position of power over the way material culture is displayed and their role in its production through persistent lobbying. These community partners are more equal than others in the control they exercise in museums and galleries.

However, the first case study also suggests that formal traditions of knowledge need not lead to exclusion. There is no reason why those who do not have regular exposure to formal academic ideas cannot understand and engage with them, albeit through their own preferred learning styles. Nevertheless, some people will always seek to prioritize traditional ways of appreciating and understanding museum objects. These ways of knowing are often important, as we have seen in the case of the Art Galleries, to some groups' understanding of the location and their own place in it. In this case people were determined to preserve a space for a certain type of exhibition because they genuinely believed that this method of displaying art, through the aesthetic perspective, was the sign of a "civilized" exhibition that upheld certain standards at a time of general economic decline. They refused to share the space, not only 
because they thought the gallery should only show conventional art historical and aesthetic exhibitions, but because they feared that sharing it would attract people who did not understand art in the way they did. They did not appreciate that their "standards" were just one way of knowing something as the later exhibition at Time and Tide illustrated.

The role of the museum is thus often that of mediator between different groups with various expectations, interests and prejudices. At every stage museum professionals, as Rice points out, have to deal with the "politics of competing interests" (Rice 2003: 2). In working in this field some community partners are more equal than others and choices have to be made, in some instances, over these competing interests, and this is not easy. Museum professionals working with communities must find their way through rival claims for certain types of collection, interpretation and display. Compromises are nearly always inevitable. Nevertheless, consultation and collaboration, sensitivity to the needs of groups, a nuanced understanding of local circumstances, will all help establish positive working relationships with all partners, although as this first case study illustrates, not all such processes will result in consensus and compromise may be impossible.

\section{Notes}

1 For the purpose of this chapter the word "museum" will be taken to include art gallery.

2 The author would like to thank all the supporters and partners of the Great Yarmouth projects described here and all the staff who worked so hard to make them happen. All opinions here are the author's own and do not represent those of any organization then or now. The author does not intend the views expressed here to be read as criticism of any existing institution, specific individual or society in Great Yarmouth.

3 A group of professional bodies working together to support the conservation and interpretation of the Borough of Great Yarmouth's heritage. The partners included the National Trust, English Heritage, the County Museums Service and the Borough Council. They came together to bid for funding to improve heritage attractions in the town and to collaborate on improvements to the historic built environment and to museums.

4 Information from "The EasyLearn Centre or Learning Shop: First draft evaluation of this project." A report by the Area Museums Officer 2000, Great Yarmouth Museum Archives.

5 "The EasyLearn Centre or Learning Shop: First draft evaluation of this project," Undated. A report by the Area Museums Officer, Great Yarmouth Museum Archives.

6 Ipsos Mori is a UK market research company. Available at www.ipsos-mori.com/ (accessed June 17, 2013).

\section{References}

Appleton, J. (2007) "Museums for the 'people'?" in S. Watson (ed.) Museums and their Communities, pp. 114-26, London and New York: Routledge.

Bennett, T. (1995) The Birth of the Museum: History, theory, politics, London and New York: Routledge.

Bennett, T., Savage, M., Silva, E., Warde, A., Gayo-Cal, M., Wright, D. (2010) Culture, Class, Distinction, London and New York: Routledge.

Benton, T. and Watson, N.J. (2010) “Museum practice and heritage," in S. West (ed.) Understanding Heritage in Practice, pp. 127-65, Manchester: Manchester University Press.

Bourdieu, P. (1984) Distinction: A Social Critique of the Judgement of Taste, London: Routledge.

Bourdieu, P. and Darbel, A. (1997) The Love of Art: European Art Museums and their Public, Oxford: Polity Press in association with Blackwell Publishers Ltd.

Businessballs.com (2010) "Demographic Classifications." Available at www.businessballs.com/demo graphicsclassifications.htm (accessed March 22, 2010).

Census (2009) “Census for England and Wales." Available at < www.statistics.gov.uk/census2001/pyramids/ pages/33ud.asp > (accessed December 1, 2009). 
Cuno, J. (1997) "Whose money? Whose power? Whose art history?" The Art Bulletin, 79 (1): 6-9.

Dubin, S. (1999) Displays of Power: memory and amnesia in the American museum, New York and London: New York University Press.

Duncan, C. (1995) Civilizing Rituals: inside public art museums, London and New York: Routledge.

Fisher, S. (1996) A Heritage Trail for Great Yarmouth: Qualitative Research: job no. 687, Great Yarmouth Museums Archives.

Gero, R. (2006) "The border of the aesthetic," in J. Elkins (ed.) Art History Versus Aesthetics, pp. 3-18, New York and London: Routledge.

GYBC (2004) Great Yarmouth Borough Council, "Indices of Deprivation 2004," internal memo in the Department of Regeneration.

Hill, K. (2005) Culture and Class in English Public Museums 1850-1914, Aldershot: Ashgate.

Hooper-Greenhill, E. (1992) Museums and the Shaping of Knowledge, London and New York: Routledge. (2000) Museums and the Interpretation of Visual Culture, London and New York: Routledge.

- (2007) "Interpretive communities, strategies and repertoires," in S. Watson (ed.) Museums and their Communities, pp. 76-94, London: Routlege.

Hooper-Greenhill, E. and Moussouri, T. 2001 Making Meaning in Art Museums 2: Visitors' interpretive strategies at Nottingham Museums and Art Galleries, Leicester: RCMG. Available at www.le.ac.uk/ms/ research/Reports/Making\%20Meaning\%202.pdf (accessed April 22, 2010).

Hooper-Greenhill, E., Moussouri, T., Hawthorne, E., Riley, R. (2001) Making Meaning in Art Museums 1: visitors' interpretive strategies at Wolverhampton Art Gallery, Leicester: RCMG. Available at www.le.ac. uk/museumstudies/research/Reports/Making\%20meaning\%201.pdf (accessed April 22, 2010).

Kant, I. (1790) (2002) Kritik der Urteilskraft (Critique of Judgment), New York: General Books LLC.

Kieran, M. (2005) "Value of art," in B. Gaut and D. McIver Lopes (eds) The Routledge Companion to Aesthetics, 2nd edn, pp. 293-305, Abingdon: Routledge.

Knell, S. (2007) "Museums, reality and the material world," in S.K. Knell (ed.) Museums in the Material World, pp. 1-28, London, Routledge.

Lagerkvist, C. (2006) "Empowerment and anger: learning how to share ownership of the museum," Museum and Society, 4 (2): 52-68.

Lloyd's (2010) "Lloyds Fact sheet no. 2." Available at www.lloyds.com/NR/rdonlyres/A868192AB7CD-4559-82C5-63D9B4BDDE36/0/LloydsHistoryandChronologyFactSheet2.pdf (accessed April 7, 2010).

McClellan, A. (2003) "Introduction," in A. McClellan (ed.) Art and its Publics: museum Studies at the Millennium, pp. xiii-xviii, Blackwell Publishing Ltd: Malden, MA, and Oxford.

MacDonald, G.F. and Alsford, S. (1995) "Canadian museums and the representation of culture in a multi-cultural nation," Cultural Dynamics, 7 (1):15-36.

Marstine, J. (ed.) (2006) New Museum Theory and Practice: An Introduction, Oxford: Blackwell Publishing.

Martin, A. (2003) The Impact of Free Entry on Museums, IPSOS MORI, March 2003. Available at www. ipsos-mori.com/DownloadPublication/541_sri-the-impact-of-free-entry-to-museums-2003.pdf (accessed January 8, 2009).

Merriman, N. (2000) Beyond the Glass Case: the past, the heritage and the public, London: University College London, Institute of Archaeology.

Norfolk Museums and Archaeological Services (no date) "Access Policy Mission Statement." Available at www.museums.norfolk.gov.uk/About_Us/Policy_Documents/Access_Policy/index.htm (accessed September 14, 2012).

NMAS (2009) Norfolk Archaeology and Museums Service leaflet Our Choice: We Know What We Like. NMAS archive.

O'Neill, M. (2002) “The good enough visitor,” in R. Sandell (ed.) Museums, Society, Inequality, pp. 24-40, London and New York: Routledge.

Prior, N. (2003) "Having one's Tate and eating it: transformations of the museum in a hypermodern era," in A. McClellan (ed.) Art and its Publics: museum studies at the millennium, pp. 51-74, Malden, Oxford and Victoria: Blackwell Publishing.

Rice, D. (2003) "Museums: Theory, practice, and illusion," in A. McClellan (ed.) Art and its Publics: museum studies at the millennium, pp. 77-95, Malden, Oxford and Victoria: Blackwell Publishing.

Sandell, R. (ed.) (2002) Museums, Society, Inequality, London and New York: Routledge.

Simpson, A. (1991) "The uses of 'cultural literacy': a British view," Journal of Aesthetic Education, 25 (4): 65-73.

Silverman, L.H. (2010) The Social Work of Museums, London and New York: Routledge. 
Simon, N. (2010) The Participatory Museum, Santa Cruz: Museum 2.0.

Trevelyan, V. (ed.) (1991) "Dingy places with different kinds of bits": an attitudes survey of London museums amongst non visitors, London: London Museums Service.

Trodd, C. (2003) "The discipline of pleasure; or, how art history looks at the art museum," Museum and Society, 1 (1): 17-29.

Urry, J. (1998) The Tourist Gaze: leisure and travel in contemporary societies, London: Sage Publications.

Warburton, D (2009) "North East tourist attractions show rise in visitor numbers," Journal Live.co.uk. Available at www.journallive.co.uk/north-east-news/breaking-news/2008/10/08/north-east-touristattractions-show-rise-in-visitor-numbers-61634-21993043/ (accessed December 1 2009).

Watson, S. (2007a) (ed.) Museums and their Communities, London and New York: Routledge.

- (2007b) "History museums, community identities and a sense of place: rewriting histories," in S. Knell, S. MacLeod, S. Watson (eds) Museum Revolutions: how museums change and are changed, pp. 160-72, London and New York: Routledge.

Watson, S., Kirk, R., and Steward, J. (2012) "Arsenic, wells and herring curing: Making new meanings in an old fish factory," in S. MacLeod, Hourston Hanks, J. Hale (eds) Museum Making: narratives, architectures, exhibitions, pp. 157-67, London and New York: Routledge.

Weil, S. (2007) "On a new foundation. The American art museum reconceived," in S.J. Knell (ed.) Museums in the Material World, pp. 100-109, London and New York: Routledge.

Wedgwood, T. (2009a) "History in two dimensions or three? Working class responses to history," International Journal of Heritage Studies, 15 (4): 277-97.

(2009b) "Partner or Pariah?-Academic attitudes to history work by mill hands at Cooleemee, North Carolina," Museum and Society, 7 (3): 178-93.

Wheeler, B. (2010) "Labour battles the BNP on class and race," 14 January 2010, BBC News Channel. Available at http://news.bbc.co.uk/1/hi/uk_politics/8454590.stm (accessed March 22, 2010). 